\title{
How Psychological Contract Breach Influences Organizational Identification and Organizational Citizenship Behavior: The Mediating Role of Psychological Capital
}

\author{
Wanjun Yang, Lin Chao* \\ School of Psychology, South China Normal University, Guangzhou, China \\ Email:670079127@qq.com, "bnuchaolin@qq.com
}

Received 25 July 2016; accepted 28 August 2016; published 31 August 2016

Copyright @ 2016 by authors and Scientific Research Publishing Inc.

This work is licensed under the Creative Commons Attribution International License (CC BY).

http://creativecommons.org/licenses/by/4.0/

(c) (i) Open Access

\begin{abstract}
This study investigates how psychological contract influences employees' extra-role contribution, such as organizational identification and organizational citizenship behavior. Specifically, it proposes the mediating role of psychological capital in the abovementioned relationships. A total of 283 employees in China completed the questionnaires. Results indicate that psychological capital partially mediates the relationship between psychological contract breach and organizational identification, and fully mediates the relationship between psychological contract breach and organizational citizenship behavior. In addition, organizational identification mediates the relationship between psychological capital and organizational citizenship behavior. Implications for future research of the current study are discussed.
\end{abstract}

\section{Keywords}

Psychological Contract Breach, Psychological Capital, Organizational Identification, Organizational Citizenship Behavior, Extra-Role Contribution

\section{Introduction}

Psychological contract is a set of unwritten mutual belief in charge between employees and organization [1]. With the fast development of economy and technology, globalization is increasingly competitive today, more and more companies are forced to adjust the organization structure, recruit talent and eliminate redundant em-

\footnotetext{
${ }^{*}$ Corresponding author.
} 
ployees so as to survive in this competitive environment. In these circumstances, employment relationships are no longer steady, and the psychological contract established by employees and organization is destroyed frequently. Psychological contract breach is becoming the focus of the experts and scholars. The empirical study found that psychological contract breach had significantly negative influence on job satisfaction [2], organizational commitment [3], in-role behavior [4], and more worse, it would lead to low job performance [5] and voluntary redundancy [6].

Social exchange theory postulates that staffs hope to pursue an impartial and balanced relationship in their workplace [7]. Psychological contract breach occurs when employees perceive a discrepancy between what they were promised and what they receive from the organization [8]. Such divergences stand for an inequality in the social exchange relationship and have been described as a sort of equitable distributes [9]. Employees are usually motivated to decrease their contribution to the organization after psychological contract breach happens in order to reinstate equality to the exchange relationship [10]. Especially extra-role contribution is a conception about additional contribution made by employees which are not required by organizational performance system. It is clear that these mental or behavioral processes could improve organizational efficiency, effectiveness and adaptability.

As pointed out by Organ, employees cannot free to increase or decrease the behavior within Official duties due to the job descriptions and Organizational regulations [11]. That is to say, whether employees get satisfactory treatment or not, they are likely to keep the same level behavior within the responsibility. By extension, extra-role contribution is not limited how to do by written contract, and could increase or decrease according to their will in the real work situation. In general, extra-role contribution is more sensitive to the change of social exchange relationship between the employees and organization. Hence, it will clearer reflect the change of relationship and understand the psychological contract management problem by observing the variation of employees' extra-role contribution. Yet prior research has not used this concept for studying the impact of psychological contract breach on organizational outcomes.

In addition, we argue that employees' psychological capital, one beneficial form of individual's resources, mediates the effect of psychological contract breach on extra-role contribution. The remainder of this article is structured as follows. We first review the existing literature on psychological contract breach, psychological capital, organizational identification, and organizational citizenship behavior. Then we propose a theoretical framework that examines how psychological contract breach declines employees' extra-role contribution. After that, we conduct an empirical study to examine our hypotheses. Finally, we discuss the implications and applications of our study.

\section{Literature Review and Theoretical Hypothesis}

\subsection{Psychological Contract Breach and Organizational Identification}

Masterson and Stamper defined that organizational identification corresponded to the belonging dimension of perceived organizational membership, that is to say one perception that individual has invested a part of one to become a member of the organization and a sense of perceived approbation by their workmates [12]. Generally speaking, it is an important component of the general representation of the employee-organization relationship. Employers are progressively aware of the fact that organizational identification is a key factor of employees' cooperation, effort, citizenship behaviors, and organizational support [13]. According to previous research, we suggest that psychological contract breach will be negatively related to organizational identification due to its bad signal that employees are not valuable members [14] [15]. Psychological contract breach will lead to employees' re-evaluation about their corporate culture as well as the abandoned feelings which will lower the employee's psychological attachment to the organization. The attractiveness of the organization may be about to decline due to above process, it will be even worse if the attractiveness is the employees' initial motivation to enter the organization. The empirical study also found that psychological contract gap would make employees frustrate to their organization and not proud to be a member of it [16]. Thus, we propose that psychological contract breach is negatively related to organizational identification.

\subsection{Psychological Contract Breach and Organizational Citizenship Behavior}

Organ initially defined organizational citizenship behavior as the discretionary behaviors which are exhibited by 
employees and not officially recognized by the organizational system, yet that generally promote the effective and efficient functioning of the organization they are belongs. It is widely recognized that organizational citizenship behavior has an important influence on organizational effectiveness, adaptability and efficiency [17]. What's more, prior research found that organizational citizenship behavior was closely linked with job satisfaction and had a positive prediction effect on psychological well-being, it can be said that organizational citizenship behavior is an important explicit indicator of employees' Mental health [18] [19]. Many empirical researches proved that psychological contract breach influenced employees' extra-role behavior. Atabay surveyed 122 employees and found that the greater the degree of psychological contract breach reported by employees, the less likely they are to engage in organizational citizenship behavior [17]. Furthermore, the influences of psychological contract breach on the negative behaviors of employees also contain reduced employees' contribution to the organizations and weakened employer-employee relations [20]. Thus, we propose that psychological contract breach will have negative influence on employee's organizational citizenship behavior.

\subsection{Psychological Contract Breach, Psychological Capital, Organizational Identification and Organizational Citizenship Behavior}

There is no empirical study about inspecting the relationship between psychological contract breach and psychological capital in currently academia. Yet we can find some related theories to state the two variables' connection from the prior study in regard to the antecedent variables of psychological capital. For instance, Shen found that the level of perceived support of social network relationship was related to individual's positive physiological and psychological reaction significantly [21]. Organizations which carry out psychological contract well will achieve employees' expect on the material reward and provide employees with a harmonious humanity environment and favorable career development channel at the same time. All of these will make employees perceive the support from social network and promote staff positive psychological state development ultimately. On the contrary, employees' positive emotions will be bruised if they perceive the organization cannot live up to its commitments, their optimistic level will be impact and lose faith and hope on their organization as time passes.

As individual's positive psychological resources, the level of psychological capital has a significant positive influence on employees' work attitude and behavior [22]. Generally, employees who are more positive would seem to exhibit more organizational citizenship behavior than employees who tend to be negative [23]. Jung's study show that psychological capital as well as its four dimensions are associated with intention and behavior of employees; the level of optimistic contributes to the positive tendency; individuals higher in resilience would persistent in pursuing goals, they will looking for a variety of ways to achieve their goals based on their abilities, some of the efforts are creative nevertheless not belong to the normal task role behavior; employees' hope and optimism among psychological capital have a significant effect on their organizational citizenship behaviors through their job satisfaction; self-efficacy help staff brave enough to adopt newfangled methods to get the job done and create extra-role benefits [24]. Furthermore, resource conservation theory posits that individuals will be less susceptible to affected by the loss of resources when they have greater amounts of resources [25]. Organizational identification implies the process which individuals define themselves and identify with organization, it is the process of self-identity to some extent, and the decline of organizational identification's level will cause the individual identity crisis which is a cognitive resources loss. As individual's important psychological resources, high level psychological capital will help employees resist the effects of this cognitive resources loss.

Finally, Social Identity Theory suggests that organizational members' identification with their organization will be associated with their attitudes and behaviors [26]. Lin stated that organizational citizenship behavior was the outcome variable of organizational identification according to their empirical research [27]. Therefore, we predict that staffs are likely to act the external behavior of organizational identification, such as citizenship and extra-role behavior rather than normative behavior, when they have a strong positive identity with their organization.

To sum up, we expect that psychological contract breach diminish employees' organizational identification and organizational citizenship behavior through weaken their psychological capital, and organizational identification may play a mediation's role in impacting the relationship between psychological capital and organizational citizenship behavior. 


\subsection{Current Study and Hypotheses}

The goal of this study is to investigate the role of psychological capital in the underlying mechanism of how psychological contract breach influences employees' extra-role contribution. Given the facts we elaborated in the preceding paragraphs, we hypothesize that 1) H1: psychological contract breach is negatively related to psychological capital; 2) H2: psychological capital is positively related to organizational identification; 3) H3: psychological capital is positively related to organizational citizenship behavior; 4) H4a: Psychological capital mediates the relationships between psychological contract Breach and organizational identification; H4b: Psychological capital mediates the relationships between psychological contract breach and organizational citizenship behavior; H4c: organizational identification mediates the relationship between psychological capital and organizational citizenship behavior. The study model is shown in Figure 1.

\section{Method}

\subsection{Participants}

We recruited a group of respondents from 13 companies in Guangzhou, Shanghai, Nanjing and Beijing, China, and 320 employees completed the online survey and 283 of them are valid (88.44\%). In the 283 valid samples, 173 (61.0\%) were females; $62.5 \%$ participants ranged in age from 16 to 25 years, 32.2\% from 26 to 35 years, $3.2 \%$ from 36 to 45 years, $2.1 \%$ from 46 to 55 years. With respect to the level of education, $80.9 \%$ had a bachelor's degree or higher.

\subsection{Measures}

Psychological contract breach: We used psychological contract breach scale by Shen [21], including 4 items. The Cronbach's alpha coefficient was 0.775 .

Psychological capital: We measured participant's psychological capital by adapting positive psychological capital questionnaire which including four subscale constructs: hope (6 items), optimism (6 items), resiliency (7 items) and self-efficacy (7 items) [28]. This study used the full-scale score as the measure of PsyCap. The Cronbach's alpha reliability was 0.921 .

Organizational identification: We adapted organizational identification scale, including 6 items with three dimensions self-categorization and labeling, sharing organizational goals and values and Sense of attachment, belonging, and membership of the organization, each subscale has two items [29]. The Cronbach's alpha coefficient was 0.935 .

Organizational citizenship behavior: This study measured OCB using the 18-item scale [30]. It is a composite of two subscales: a nine-item scale directed towards individuals (OCBI) and a nine-item scale directed towards the organization (OCBO). The Cronbach's alpha coefficient was 0.947.

We assessed all items using seven-point Likert scales ( 1 = completely disagree, 7 = completely agree). After data collation, the study used SPSS 17.0 and Mplus 7.0 to analyze the data.

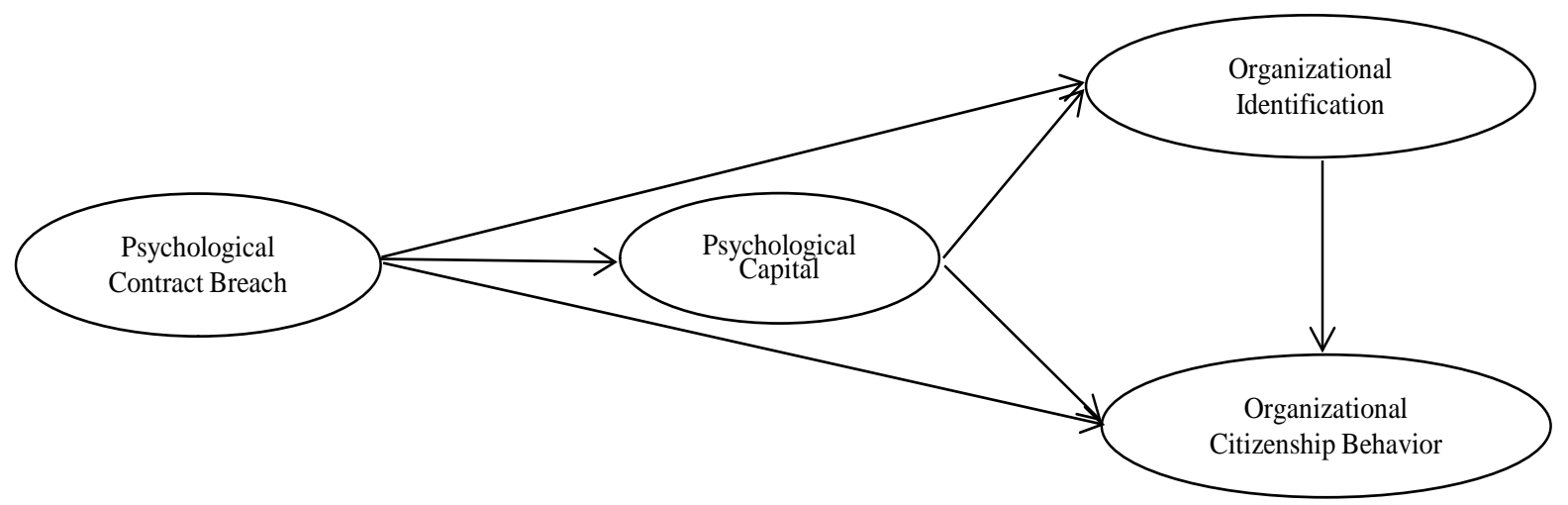

Figure 1. The effect of psychological contract breach on organizational identification and organizational citizenship behavior. 


\subsection{Common Method Biases Test}

In the structural equation model, the fitting indices of one factor structure model $\left(\chi^{2} / d f=13.149\right.$, SRMR $=0.117$, $C F I=0.667, T L I=0.600)$ was worse than four factors structure $\left(\chi^{2} / d f=2.968, S R M R=0.056, C F I=0.951, T L I\right.$ $=0.935$ ), what's more the fitting indices of four factors model was significant better than the single factor model $\left(\Delta \chi^{2} / \Delta d f=113.265, P<0.001\right)$. The confirmatory factor analysis results show that the common method bias passes the test in this study.

\section{Results}

\subsection{Correlations among Study Variables}

Table 1 presents the correlations among psychological contract breach, psychological capital, organizational identification and organizational citizenship behavior. Psychological contract breach was negatively associated with psychological capital $(r=-0.236, P<0.01)$, organizational identification $(r=-0.417, P<0.01)$ and organizational citizenship behavior $(r=-0.384, P<0.01)$. Psychological capital was positively associated with organizational identification $(r=0.509, P<0.01)$ and organizational citizenship behavior $(r=0.632, P<0.01)$. In addition, organizational identification was positively correlated with organizational citizenship behavior $(r=$ $0.73, P<0.01)$.

\subsection{Structural Model}

To examine our hypotheses, we compared a series of structural models. The baseline model, Model 1, is partial mediation model that includes the paths from psychological contract breach to psychological capital, psychological capital to organizational identification and organizational citizenship behavior, psychological contract breach to organizational identification and organizational citizenship behavior, and organizational identification to organizational citizenship behavior. In model 2, we omitted the direct path from organizational identification to organizational citizenship behavior. In model 3 , we omitted the direct path from psychological contract breach to organizational citizenship behavior. In model 4, we omitted the direct path from psychological contract breach to organizational identification. The results are shown in Table 2.

Table 1. Descriptive statistics and correlations between the variables.

\begin{tabular}{|c|c|c|c|c|c|c|c|c|}
\hline & Mean & SD & 1 & 2 & 3 & 4 & 5 & 6 \\
\hline 1. Gender & 0.61 & 0.49 & - & & & & & \\
\hline 2. Age & 3.55 & 0.66 & 0.029 & - & & & & \\
\hline 3. Education & 3.14 & 0.61 & 0.047 & -0.049 & - & & & \\
\hline 4. Psychological contract breach & 3.72 & 1.13 & 0.008 & 0.027 & $0.161^{* *}$ & - & & \\
\hline 5. Psychological capital & 4.81 & 0.78 & $-0.128^{*}$ & -0.053 & -0.103 & $-0.236^{* *}$ & - & \\
\hline 6. Organizational identification & 4.97 & 1.24 & -0.026 & -0.098 & -0.055 & $-0.417^{* *}$ & $0.509^{* *}$ & - \\
\hline 7. Organizational citizenship behavior & 5.23 & 0.96 & -0.018 & -0.089 & -0.078 & $-0.384^{* *}$ & $0.632^{* *}$ & $0.73^{* *}$ \\
\hline
\end{tabular}

Notes: $N=283$. Gender: $0=$ male, $1=$ female. Age: $1=$ more than 46 years, $2=36-45$ years, $3=26-35$ years, $4=$ less than 25 years. Education: 1 = doctor, 2 = master, 3 = undergraduate, 4 = college, 5 = Technical secondary school. ${ }^{*} P<0.05 ;{ }^{* *} P<0.01$.

Table 2. Comparisons of structural equation models.

\begin{tabular}{|c|c|c|c|c|c|c|}
\hline Model specifications & $\chi^{2}$ & df & $\Delta \chi^{2}$ & CFI & TLI & SRMR \\
\hline 1: $\mathrm{PCB} \rightarrow$ PsyCap $\rightarrow$ OI + OCB $\&$ PCB $\rightarrow$ OI + OCB $\&$ OI $\rightarrow$ OCB $^{\text {ab }}$ & 175.094 & 59 & - & 0.951 & 0.935 & 0.056 \\
\hline 2: $\mathrm{PCB} \rightarrow$ PsyCap $\rightarrow$ OI + OCB $\&$ PCB $\rightarrow$ OI + OCB & 257.755 & 60 & $82.661^{* *}$ & 0.917 & 0.891 & 0.071 \\
\hline 3: $\mathrm{PCB} \rightarrow$ PsyCap $\rightarrow$ OI + OCB $\&$ PCB $\rightarrow$ OI $\&$ OI $\rightarrow$ OCB & 178.902 & 60 & 3.808 & 0.950 & 0.935 & 0.057 \\
\hline 4: $\mathrm{PCB} \rightarrow$ PsyCap $\rightarrow$ OI + OCB $\&$ PCB $\rightarrow$ OCB $\&$ OI $\rightarrow$ OCB & 199.758 & 60 & $24.664^{* *}$ & 0.941 & 0.923 & 0.078 \\
\hline
\end{tabular}

Note: $N=283 . \Delta \chi^{2}$ is the change of $\chi^{2}$ compared with the baseline model. ${ }^{\mathrm{a} B a s e l i n e ~ m o d e l . ~}{ }^{\mathrm{b}} \mathrm{PCB}=$ Psychological Contract Breach; PsyCap $=$ Psychological Capital; OI = Organizational Identification; OCB = Organizational Citizenship Behavior. ${ }^{* *} P<0.01$. 
Results demonstrated that Model 1 fits the data well $\left(\chi^{2}=175.094, d f=59\right)$. When we removed the direct path from psychological contract breach to organizational citizenship behavior in model $3, \chi^{2}$ was increased $\left(\chi^{2}\right.$ $=178.902, d f=60)$. However, the change was not significant $\left(\Delta \chi^{2}=3.808\right.$, n.s. $)$. We selected Model 3 for parsimony. That is, psychological capital fully mediated the effect of psychological contract breach on organizational citizenship behavior and partially mediated its effect on organizational identification. In addition, organizational identification partially mediated the effect of psychological capital on organizational citizenship behavior.

Figure 2 showed the path coefficients of our final selected model. The path from psychological contract breach to psychological capital was significant $(\beta=-0.414, P<0.01$ ), supporting Hypothesis 1 . The paths from psychological capital to both organizational identification $(\beta=0.480, P<0.01)$ and organizational citizenship behavior $(\beta=0.454, P<0.01)$ were significant, which supported Hypothesis 2 and Hypothesis 3 , respectively. Finally, the mediating effects of psychological capital and organizational identification proposed in Hypothesis 4 were supported. Because the direct path (1) from psychological contract breach to organizational identification was significant $(\beta=-0.298, P<0.01)$, and the direct path (2) from psychological capital to organizational citizenship behavior was also significant $(\beta=0.454, P<0.01)$. Psychological capital and organizational identification play the partially mediate role respectively.

To further test Hypothesis 4, we adopted the bootstrapping approach to evaluate the significance of the mediating role of psychological capital in our hypothesis model [31]. Table 3 showed the indirect effects and their 95\% confidence intervals. As demonstrated in Table 3, the direct effects of psychological contract breach on psychological capital, psychological capital on both organizational identification and organizational citizenship behavior, organizational identification on organizational citizenship behavior were all significant. The indirect effects of psychological contract breach on organizational identification and organizational citizenship behavior through psychological capital, and psychological capital on organizational citizenship behavior were also significant.

\section{Discussion}

In this study, we developed a theoretical model to explore how psychological contract breach influences employees' extra-role contribution. Specifically, we adopted organizational identification and organizational citizenship behavior as indicators of employees' extra-role contribution and then examined psychological capital as a mediator in the relationship between psychological contract breach and employees' extra-role contribution. We conducted an online survey to collect data from 283 employees in China. As we proposed, correlation analyses showed that psychological contract breach was negatively related to psychological capital, which is also demonstrated by Tian [32]. Results also indicated that psychological capital was positively related to organizational identification and organizational citizenship behavior [23]. Path analysis further supported our hypotheses that psychological contract breach was negatively associated with psychological capital which in turn weaken organizational identification and organizational citizenship behavior. Moreover, path analysis showed that psychological capital fully mediated the relationships between psychological contract breach and organizational citizenship behavior, and partially mediated psychological contract breach and organizational identification. With respect to the partial mediation, The possible reason was that organizational identification was a psychological

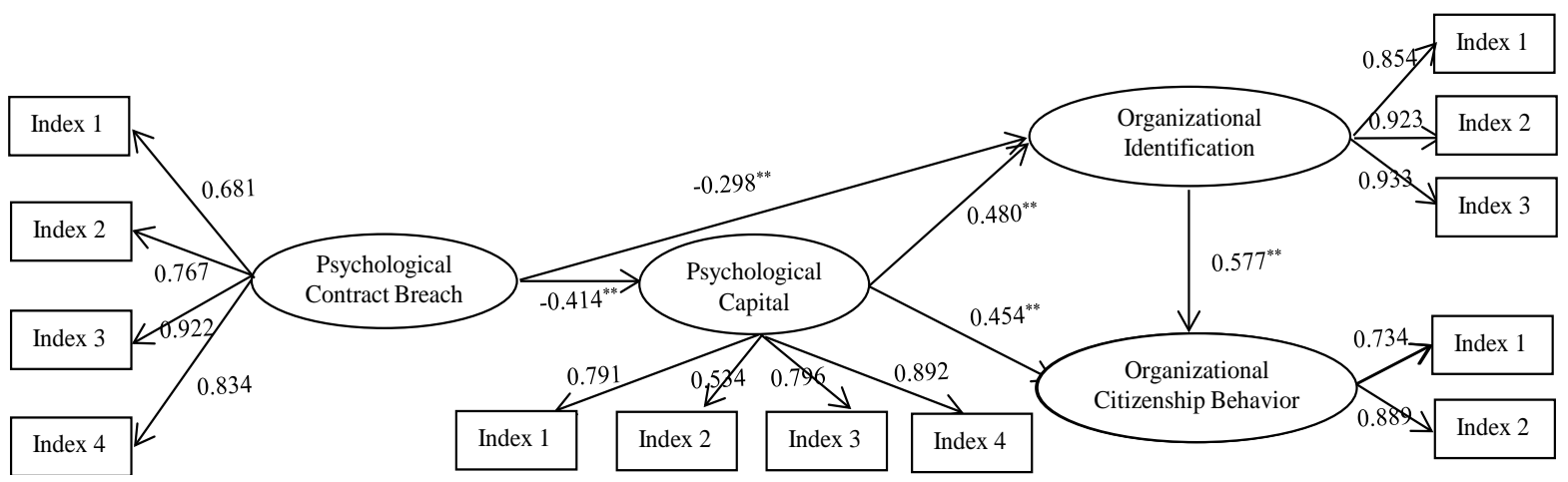

Figure 2. Path coefficients of the hypothesized model. Notes: $N=283$. Standardized path coefficients are reported here. ${ }^{* *} P$ $<0.01$. 
Table 3. Direct and indirect effects and 95\% confidence intervals.

$\begin{array}{llc}\text { Direct effects } & & \\ \text { Psychological Contract Breach } \rightarrow \text { Psychological Capital } & -0.414^{* *} & {[-3.039,-1.209]} \\ \text { Psychological Capital } \rightarrow \text { Organizational Identification } & 0.480^{* *} & {[0.127,0.303]} \\ \text { Psychological Capital } \rightarrow \text { Organizational Citizenship Behavior } & 0.454^{* *} & {[0.385,0.763]} \\ \text { Psychological Contract Breach } \rightarrow \text { Organizational Identification } & -0.298^{* *} & {[-0.987,-0.297]} \\ \text { Organizational Identification } \rightarrow \text { Organizational Citizenship Behavior } & 0.577^{* *} & {[1.222,2.053]} \\ \text { Indirect effects } & & {[-0.288,-0.110]} \\ \text { Psychological Contract Breach } \rightarrow \text { Psychological Capital } \rightarrow \text { Organizational Identification } & -0.199^{* *} & -0.188^{* *} \\ \text { Psychological Contract Breach } \rightarrow \text { Psychological Capital } \rightarrow \text { Organizational Citizenship Behavior } & {[-0.275,-0.101]} \\ \text { Psychological Capital } \rightarrow \text { Organizational Identification } \rightarrow \text { Organizational Citizenship Behavior } & 0.277^{* *} & {[0.183,0.371]}\end{array}$

Note: $N=283 .{ }^{\mathrm{a}} \mathrm{CI}=$ confidence interval. ${ }^{* *} \mathrm{P}<0.01$.

variable which would easier influenced by cognitive factors such as psychological contract breach. Therefore the direct path from psychological contract breach to organizational identification was still significant, even though the impact is weaken by employees' psychological capital.

\section{Implication}

This article has meaningful implications both in theoretical and practical. First of all, we use extra-role contribution to study the influence of psychological contract breach, As outlined in the introduction, extra-role contribution are more sensitive to the change of psychological contract, hence the results will be more significant, our study support these propose. Further research could be carried out to enrich the concept of extra-role contribution through searching and testing other variables. Beside, our findings have significant implication for practice. Employees' extra-role contribution is of great importance for both employees and organizations. Individuals with high level of organizational identification and organizational citizenship behavior will be more productive, dedicated, and loyal [33]. Its importance should be realized by employers. Specifically, the results of our study revealed that psychological contract breach is the damage factor of the employees' extra-role contribution and while psychological capital is the protective factor. So we suggest that managers should be sensitive to the change of psychological contract and make efforts to enhance the employees’ psychological at the same time.

\section{Limitations and Directions for Future Research}

Some limitations of this study should be addressed. For instance, we adopted a cross-sectional design. Therefore, our data provided limited support for causal inferences. Further research may adopt a longitudinal design to confirm causal relationships among psychological contract breach, psychological capital, organizational identification, and organizational citizenship behavior. Secondly, the present study relied solely on self-report measures. Future research may design an intervention study to improve the preciseness of our research.

\section{Acknowledgements}

This paper is supported by project of key research base for humanities and social sciences of ministry of education "The study of the structure of the well-being and its intervention" (12JJD190005).

\section{References}

[1] Chambel, M.J. (2014) Does the Fulfillment of Supervisor Psychological Contract Make a Difference? Leadership \& Organization Development Journal, 35, 20-37. http://dx.doi.org/10.1108/LODJ-03-2012-0031

[2] Wang, Y. and Hsieh, H. (2014) Employees’ Reactions to Psychological Contract Breach: A Moderated Mediation 
Analysis. Journal of Vocational Behavior, 85, 57-66. http://dx.doi.org/10.1016/j.jvb.2014.04.003

[3] Cassar, V. and Briner, R.B. (2011) The Relationship between Psychological Contract Breach and Organizational Commitment: Exchange Imbalance as a Moderator of the Mediating Role of Violation. Journal of Vocational Behavior, 78, 283-289. http://dx.doi.org/10.1016/j.jvb.2010.09.007

[4] Abu-Doleh, J. and Hammou, M.D. (2015) The Impact of Psychological Contract Breach on Organizational Outcomes: The Moderating Roll of Personal Beliefs. Journal of Competitiveness Studies, 23, 34-54.

[5] Lee, J., Chaudhry, A. and Tekleab, A.G. (2014) An Interactionist Perspective on Employee Performance as a Response to Psychological Contract Breach. Personnel Review, 43, 861-880. http://dx.doi.org/10.1108/PR-10-2012-0173

[6] Clinton, M.E. and Guest, D.E. (2014) Psychological Contract Breach and Voluntary Turnover: Testing a Multiple Mediation Model. Journal of Occupational and Organizational Psychology, 87, 200-204. http://dx.doi.org/10.1111/joop.12033

[7] Homans, G.C. (1961) Social Behavior: Its Elementary Forms. Harcourt, Brace, Oxford.

[8] Morrison, E.W. and Robinson, S.L. (1997) When Employees Feel Betrayed: A Model of How Psychological Contract Violation Develops. Academy of Management: The Academy of Management Review, 22, 226-256.

[9] Suazo, M.M., Turnley, W.H. and Mai-Dalton, R. (2005) The Role of Perceived Violation in Determining Employees' Reactions to Psychological Contract Breach. Journal of Leadership \& Organizational Studies, 12, 24-36. http://dx.doi.org/10.1177/107179190501200104

[10] Turnley, W.H., Bolino, M.C., Lester, S.W. and Bloodgood, J.M. (2003) The Impact of Psychological Contract Fulfillment on the Performance of In-Role and Organizational Citizenship Behaviors. Journal of Management, 29, 187. http://dx.doi.org/10.1177/014920630302900204

[11] Organ, D.W. (1988) Organizational Citizenship Behavior: The Good Soldier Syndrome. Lexington Books/D. C. Heath and Com, Lexington, MA.

[12] Masterson, S.S. and Stamper, C.L. (2003) Perceived Organizational Membership: An Aggregate Framework Representing the Employee-Organization Relationship Dagger. Journal of Organizational Behavior, 24, 473-490. http://dx.doi.org/10.1002/job.203

[13] Cooper, D. and Thatcher, S.M.B. (2010) Identification in Organizations: The Role of Self-Concept Orientations and Identification Motives. The Academy of Management Review, 35, 516-538. http://dx.doi.org/10.5465/AMR.2010.53502693

[14] Restubog, S.L.D., Hornsey, M.J., Bordia, P. and Esposo, S.R. (2008) Effects of Psychological Contract Breach on Organizational Citizenship Behaviour: Insights from the Group Value Model. The Journal of Management Studies, 45, 1377-1400. http://dx.doi.org/10.1111/j.1467-6486.2008.00792.x

[15] Zagenczyk, T.J., Gibney, R., Few, W.T. and Scott, K.L. (2011) Psychological Contracts and Organizational Identification: The Mediating Effect of Perceived Organizational Support. Journal of Labor Research, 32, 254-281. http://dx.doi.org/10.1007/s12122-011-9111-z

[16] Zagenczyk, T.J., Cruz, K.S., Woodard, A.M., Walker, J.C., Few, W.T., Kiazad, K. and Raja, M. (2013) The Moderating Effect of Machiavellianism on the Psychological Contract Breach-Organizational Identification/Disidentification Relationships. Journal of Business and Psychology, 28, 287-299. http://dx.doi.org/10.1007/s10869-012-9278-1

[17] Jafri, M.H. (2012) Influence of Psychological Contract Breach on Organizational Citizenship Behaviour and Trust. Psychological Studies, 57, 29-36. http://dx.doi.org/10.1007/s12646-011-0112-z

[18] Rastogi, R. and Garg, P. (2011) Organizational Citizenship Behavior: Towards Psychological Well-Being of Employees. International Journal of Arts \& Sciences, 4, 13-30.

[19] Talachi, R.K., Gorji, M.B. and Boerhannoeddin, A. B. (2014) An Investigation of the Role of Job Satisfaction in Employees’ Organizational Citizenship Behavior. Collegium Antropologicum, 38, 429-436.

[20] Robinson, S.L., Kraatz, M.S. and Rousseau, D.M. (1994) Changing Obligations and the Psychological Contract: A Longitudinal Study. Academy of Management Journal, 37, 137-152. http://dx.doi.org/10.2307/256773

[21] Shen, Y.M. and Yuan, D.H. (2007) The Impact of Psychological Contract Breach on the Work-Related Attitude and Behavior of Bmployees. Acta Psychologica Sinica, 39, 155-162.

[22] Beal Loyd, I., Stavros, J.M. and Cole, M.L. (2013) Effect of Psychological Capital and Resistance to Change on Organisational Citizenship Behaviour. Journal of Industrial Psychology, 39, 1-11.

[23] Avey, J.B., Luthans, F. and Youssef, C.M. (2010) The Additive Value of Positive Psychological Capital in Predicting Work Attitudes and Behaviors. Journal of Management, 36, 430-452. http://dx.doi.org/10.1177/0149206308329961

[24] Jung, H.S. and Yoon, H.H. (2015) The Impact of Employees' Positive Psychological Capital on Job Satisfaction and Organizational Citizenship Behaviors in the Hotel. International Journal of Contemporary Hospitality Management, 


\section{7, 1135-1156. http://dx.doi.org/10.1108/IJCHM-01-2014-0019}

[25] Cao, X. (2014) Analysis of Origins and Main Contents of Conservation of Resource Theory and Implications. Human Resources Development of China, 15, 75-80.

[26] Van Dick, R., Grojean, M.W., Christ, O. and Wieseke, J. (2006) Identity and the Extra Mile: Relationships between Organizational Identification and Organizational Citizenship Behaviour. British Journal of Management, 17, $283-301$. http://dx.doi.org/10.1111/j.1467-8551.2006.00520.x

[27] Lin, Q. and Shen, C.H. (2012) Empirical Study on the Relationships between Organizational Justice, Organizational Identification and Organizational Citizenship Behavior. Accounting and Finance, 2, 71-78.

[28] Zhang, K., Zhang, S. and Dong, Y.H. (2010) Positive Psychological Capital: Measurement and Relationship with Mental Health. Studies of Psychology and Behavior, 8, 58-64.

[29] Edwards, M.R. and Peccei, R. (2007) Organizational Identification: Development and Testing of a Conceptually Grounded Measure. European Journal of Work and Organizational Psychology, 16, 25-57. http://dx.doi.org/10.1080/13594320601088195

[30] Lee, K. and Allen, N.J. (2002) Organizational Citizenship Behavior and Workplace Deviance: The Role of Affect and Cognitions. Journal of Applied Psychology, 87, 131-142. http://dx.doi.org/10.1037/0021-9010.87.1.131

[31] MacKinnon, D.P., Lockwood, C.M. and Williams, J. (2004) Confidence Limits for the Indirect Effect: Distribution of the Product and Resampling Methods. Multivariate Behavioral Research, 39, 99-128. http://dx.doi.org/10.1207/s15327906mbr3901_4

[32] Tian, X.Z. (2009) The Influence of Psychological Capital and Psychological Contract on Work Attitude and Behavior. Modernization of Management, 4, 12-14.

[33] Norman, S.M., Avey, J.B., Nimnicht, J.L. and Graber Pigeon, N. (2010) The Interactive Effects of Psychological Capital and Organizational Identity on Employee Organizational Citizenship and Deviance Behaviors. Journal of Leadership \& Organizational Studies, 17, 380-391. http://dx.doi.org/10.1177/1548051809353764

\section{Submit or recommend next manuscript to SCIRP and we will provide best service for you:}

Accepting pre-submission inquiries through Email, Facebook, LinkedIn, Twitter, etc.

A wide selection of journals (inclusive of 9 subjects, more than 200 journals)

Providing 24-hour high-quality service

User-friendly online submission system

Fair and swift peer-review system

Efficient typesetting and proofreading procedure

Display of the result of downloads and visits, as well as the number of cited articles

Maximum dissemination of your research work

Submit your manuscript at: http://papersubmission.scirp.org/ 